\title{
APLIKASI GIBERELIN (GA, $)$ DAN PUPUK DAUN UNTUK MENINGKATKAN PRODUKSI LADA PERDU
}

\section{APPLICATION OF GIBBERELLIN (GA,) AND FOLIAR FERTILIZER TO INCREASE PEPPER SHRUB PRODUCTION}

\author{
Adryade Reshi Gusta*, Made Same, Kresna Shifa Usodri, Delva Yulianingrum \\ Estate Crops Department, Politeknik Negeri Lampung, Lampung, Indonesia. \\ *Email:adryade@polinela.ac.id \\ *Corresponding Author, Diterima: 10 Mei 2021, Direvisi: 24 Juni 2021, Disetujui: 30 Ags. 2021
}

\begin{abstract}
Pepper (Piper nigrum L.) is an annual plant that is widely used as a spice, cooking spices, and medicine. Efforts to increase pepper production in Indonesia, especially in Lampung, so that it does not decrease every year. The aim of this study was to find the best combination of gibberellin concentration (GA $A_{3}$ and foliar fertilizer spray volume to increase the production of herbaceous pepper. The research was conducted in the Lampung State Polytechnic garden, from August 2019 to February 2020, using a factorial randomized completelyblock design (RCBD) with 15 treatment combinations and 3 replications. The first factor is the concentration of $\mathrm{GA}_{3}$ and the second factor was the volume offoliar fertilizer spray. Analysis of research data using the F test, if there is a difference, it is followed by the BNT test at 5\% level. The results showed that the treatment of gibberellin concentration $\left(G A_{3}\right)$ had no effect on the observation of stem diameter, number of branches, number of flowers, but had an effect on the number of internodes, number of fruit and fruit weight at the levels of $150 \mathrm{~mL} \mathrm{~L} \mathrm{~L}^{-1}$ (G3) and $200 \mathrm{~mL} \mathrm{~L}^{-1}$ (G4). Treatment of foliar fertilizer spray volume on the observation of stem diameter, number of internodes, number of fruit and fruit weight had no effect, but had an effect on the number of branches and the number of flowers at the 200 mLlevel (D2). The interaction of gibberellin $\left(G A_{3}\right)$ and foliar fertilizer resulted in stem diameter, number of branches, number of internodes, number of fruits and fruit weight which had no effect, but had an effect on the number of flowers in the combination of gibberellin concentration $\left(G A_{3}\right) 100 \mathrm{~mL} \mathrm{~L}^{-1}$ with a volume of $100 \mathrm{~mL}$ foliar fertilizer spray.
\end{abstract}

Keywords: Foliar fertilizer, gibberellin $\left(G A_{3}\right)$, pepper shrub, production.

\begin{abstract}
ABSTRAK
Lada merupakan tanaman tahunan yang banyak dimanfaatkan sebagai rempah, bumbu masak, dan obat. Upaya peningkatan produksi lada di Indonesia khususnya di Lampung agar tidak semakin menurun tiap tahunnya. Penelitian bertujuan untuk mendapatkan kombinasi antara konsentrasi giberelin $\left(\mathrm{GA}_{3}\right)$ dan volume semprot pupuk daun yang terbaik untuk meningkatkan produksi tanaman lada perdu (Piper nigrum L.). Penelitian dilaksanakan di kebun Politeknik Negeri Lampung, pada bulan Agustus 2019 sampai dengan Februari 2020, menggunakan Rancangan Acak Kelompok (RAK) pola faktorial dengan 15 kombinasi perlakuan dan 3 ulangan. Faktor pertama adalah konsentrasi $\mathrm{GA}_{3}(\mathrm{G}): 0 \mathrm{~mL} \mathrm{~L}^{-1}\left(\mathrm{G}_{0}\right), 50 \mathrm{~mL} \mathrm{~L}^{-1}\left(\mathrm{G}_{1}\right), 100 \mathrm{~mL} \mathrm{~L}^{-1}\left(\mathrm{G}_{2}\right), 150 \mathrm{~mL} \mathrm{~L}^{-1}\left(\mathrm{G}_{3}\right)$, dan $200 \mathrm{~mL} \mathrm{~L}^{-}$
\end{abstract}


${ }^{1}\left(G_{4}\right)$. Faktor kedua adalah volume semprot pupuk daun $(D): 0 \mathrm{ml}\left(\mathrm{D}_{0}\right), 100 \mathrm{ml}\left(\mathrm{D}_{1}\right)$, dan $200 \mathrm{ml}\left(\mathrm{D}_{2}\right)$. Analisis data penelitian menggunakan uji F, jika ada perbedaan maka dilanjutkan dengan uji BNT taraf $5 \%$. Hasil penelitian menunjukkan bahwa perlakuan konsentrasi giberelin $\left(\mathrm{GA}_{3}\right)$ tidak berpengaruh pada pengamatan diameter batang, jumlah cabang, jumlah bunga, tetapi berpengaruh terhadap jumlah ruas, jumlah buah dan bobot buah pada taraf $150 \mathrm{~mL} \mathrm{~L}^{-1}\left(\mathrm{G}_{3}\right)$ dan $200 \mathrm{~mL} \mathrm{~L}^{-1}\left(\mathrm{G}_{4}\right)$. Perlakuan volume semprot pupuk daun pada pengamatan diameter batang, jumlah ruas, jumlah buah dan bobot buah yang tidak berpengaruh, tetapi berpengaruh terhadap jumlah cabang dan jumlah bunga pada taraf $200 \mathrm{ml}\left(\mathrm{D}_{2}\right)$. Interaksi giberelin $\left(\mathrm{GA}_{3}\right)$ dan pupuk daun menghasilkan diameter batang, jumlah cabang, jumlah ruas, jumlah buah dan bobot buah yang tidak berpengaruh, tetapi berpengaruh terhadap jumlah bunga pada kombinasi konsentrasi giberelin $\left(\mathrm{GA}_{3}\right) 100 \mathrm{~mL} \mathrm{~L}^{-1}$ dengan volume semprot pupuk daun $100 \mathrm{ml}$.

Kata kunci : Giberelin, lada perdu, produksi, pupuk daun.

\section{PENDAHULUAN}

Lada (Piper nigrum L.) merupakan tanaman tahunan yang tumbuh memanjat dan banyak dimanfaatkan sebagai rempah, bumbu masak, dan obat, lada sering disebut sebagai king of spices (Srinivasan, 2007). Lada juga merupakan sektor yang berpotensi dalam pengembangan devisa negara (Kementerian Pertanian, 2019). Rendahnya produksi lada di Lampung pada tahun 2019 yaitu hanya sebesar 499,10 kg/ha maka perlu dilakukan upaya peningkatan produksi lada di Indonesia khususnya di Lampung agar tidak semakin menurun tiap tahunnya. Salah satu upaya meningkatkan produksi lada dengan pemberian ZPT (zat pengatur tumbuh) dan pupuk yang tepat. ZPT merupakan suatu senyawa organik bukan nutrisi yang dalam konsentrasi rendah dapat mendorong, menghambat atau secara kualitatif mengubah pertumbuhan dan perkembangan pada tanaman. Salah satu ZPT yang sering digunakan yaitu giberelin $\left(\mathrm{GA}_{3}\right)$ yang memiliki banyak peran dalam mempengaruhi berbagai proses fisiologi tanaman. Hal ini telah dibuktikan oleh Sunardi, dkk. (2013) pada penelitiannya bahwa tanaman kangkung yang diberikan perlakuan $15 \mathrm{~mL} \mathrm{~L}^{-1} \mathrm{GA}_{3}$ berpengaruh nyata meningkatkan bobot basah dan bobot kering tanaman dengan nilai bobot basah 6,80 bobot basah, $61,9 \%$ berbeda dari Go $\left(0 \mathrm{~mL} \mathrm{~L}^{-1} \mathrm{GA}_{3}\right)$. Bobot kering brangkasan 9,00 gram, berbeda nyata $64 \%$ dari titik tengah terkecil. Giberelin $\left(\mathrm{GA}_{3}\right)$ mampu mempengaruhi sifat genetik dan proses fisiologi yang terdapat dalam tumbuhan, seperti merangsang pembungaan, partenokarpi, mempercepat perkecambahan biji, pertumbuhan tunas tanaman, pemanjangan batang, dan mobilisasi karbohidrat selama masa perkecambahan berlangsung (Yasmin dkk., 2014).

Kandungan dan ketersediaan unsur hara dapat mempengaruhi hasil produksi lada. Upaya untuk memperbaiki hasil produksi lada di provinsi Lampung yaitu dengan pemupukan pada tanaman lada. Aplikasi pemupukan yang dilakukan dengan pemberian pupuk ke dalam tanah dan penyemprotan seluruh bagian tanaman (terutama melalui daun). Pupuk daun merupakan pupuk buatan yang memiliki unsur hara tertentu yang dapat memenuhi kebutuhan unsur hara oleh tanaman dari dalam tanah sehingga penggunaan pupuk anorganik dapat disesuaikan dengan kebutuhan tanaman. 
Penelitian ini bertujuan untuk mendapatkan konsentrasi $\mathrm{GA}_{3}$ terbaik terhadap pertumbuhan dan produksi lada perdu, mendapatkan volume semprot pupuk daun terbaik terhadap pertumbuhandan produksi lada perdu dan mendapatkan interaksi antara konsentrasi $\mathrm{GA}_{3}$ dan volume semprot pupuk daun terhadap pertumbuhan dan produksi lada perdu.

\section{BAHAN DAN METODE}

Percobaan ini dilaksanakan di kebun Politeknik Negeri Lampung. Dari bulan Agustus 2019 sampai dengan Februari 2020.Alat yang digunakan dalam percobaan adalah timbangan, hand sprayer, gembor, cangkul, kored, mistar, jangka sorong, dan labu takar. Bahan yang digunakan dalam penelitian adalah bibit lada perdu dari Balai Besar Kebun Induk (BBKI) Provinsi Lampung berumur 12 bulan. Bahan lain adalah Giberelic Acid $\left(\mathrm{GA}_{3}\right)$, dan pupuk daun Growmore pot berdiameter $30 \mathrm{~cm}$, label, dan alat tulis.Penelitian ini menggunakan rancangan acak kelompok (RAK) berpola faktorial dengan 3 ulangan.

Faktor pertama adalah konsentrasi $\mathrm{GA}_{3}(\mathrm{G})$ antara lain: $0 \mathrm{~mL} \mathrm{~L}^{-1}\left(\mathrm{G}_{0}\right), 50 \mathrm{~mL} \mathrm{~L}^{-1}\left(\mathrm{G}_{1}\right), 100 \mathrm{~mL} \mathrm{~L}^{-1}$ $\left(\mathrm{G}_{2}\right), 150 \mathrm{~mL} \mathrm{~L}^{-1}\left(\mathrm{G}_{3}\right)$, dan $200 \mathrm{~mL} \mathrm{~L}^{-1}\left(\mathrm{G}_{4}\right)$. Faktor kedua adalah volume semprot pupuk daun (D) antara lain : $0 \mathrm{ml}\left(\mathrm{D}_{0}\right), 100 \mathrm{ml}\left(\mathrm{D}_{1}\right), \operatorname{dan} 200 \mathrm{ml}\left(\mathrm{D}_{2}\right)$. Analisis data dilakukan dengan sidik ragam (uji F) pada taraf nyata 5\%, dan jika terdapat perbedaan pengaruh yang signifikan, dilanjutkan dengan menggunakan uji Beda Nyata Terkecil (BNT).Penelitian ini terdapat 15 kombinasi perlakuan yang masing-masing diulang $3 \mathrm{kali}$ sehingga secara keseluruhan terdapat 45 satuan percobaan.

\section{Pembuatan Larutan Stok dan Penyemprotan GA} Pembuatan larutan stok

Pembuatan larutan stok GA 3100 ppm, maka dengan menimbang $0,1 \mathrm{~g} \mathrm{GA}_{3}$. Kemudian meneteskan alkohol sampai $\mathrm{GA}_{3}$ larut dan menambahkan aquades kedalam labu takar sampai volume 1000mL(1 Liter). Penyemprotan $\mathrm{GA}_{3}$

Pemberian zat pengatur tumbuh $\mathrm{GA}_{3}$ dilakukan dengan menggunakan hand sprayer, yaitu menyemprotkanGA ${ }_{3}$ dengan perlakuan $(\mathrm{G} 0) 0 \mathrm{~mL} \mathrm{~L}^{-1}$ (kontrol), (G1) $50 \mathrm{~mL} \mathrm{~L}^{-1}$, (G2) $100 \mathrm{~mL} \mathrm{~L}^{-1}$, (G3) 150 $\mathrm{mL} \mathrm{L}^{-1}$, dan (G4) $200 \mathrm{~mL} \mathrm{~L}^{-1}$ keseluruh permukaan tanaman masing-masing sebanyak $50 \mathrm{~mL}$ (sesuai dengan kalibrasi yang dilakukan sebelum penyemprotan $\mathrm{GA}_{3}$ ). Aplikasi pertama dilakukan 4 minggu setelah tanam kemudian diulang sebanyak tiga kali dengan interval 4 minggu sekali.

\section{Pembuatan Larutan Stok dan Penyemprotan} Pupuk Daun

\section{Pembuatan Larutan}

Pembuatan larutan untuk (D0) $0 \mathrm{ml}$ (kontrol), (D1) $100 \mathrm{ml}$, dan (D2) $200 \mathrm{ml}$ dilakukan sebelum penyemprotan. Ditimbang $2 \mathrm{~g}$ pupuk daun, kemudian tambahkan air ke dalam labu takar sampai volume $1000 \mathrm{~mL}$ (1 Liter).

\section{Penyemprotan pupuk daun}

Pemberian pupuk daun dilakukan dengan menggunakan hand sprayer, yaitu menyemprotkan pupuk daun sesuai dengan perlakuan (D0) $0 \mathrm{ml}$ (kontrol), (D1) $100 \mathrm{ml}$, dan (D2) $200 \mathrm{ml}$ keseluruh permukaan tanaman. Pemberian pupuk daun dilakukan 4minggu setelah tanam kemudian diulang sebanyak tiga kali dengan interval 4 minggu sekali. 


\section{Parameter yang Diamati}

Perubahan yang diamati dalam percobaan ini antara lain: diameter batang (mm), jumlah cabang (tangkai), jumlah ruas (buah), waktu tumbuh bunga, jumlah bunga (tangkai), jumlah buah (tangkai), dan bobot buah (gram).

\section{HASIL DAN PEMBAHASAN}

\section{Respons Diameter Batang terhadap Pemberian} Konsentrasi Giberelin $\left(\mathrm{Ga}_{3}\right)$ dan Volume Semprot Pupuk Daun pada Tanaman Lada Perdu

Hasil rata--- rata diameter batang tanaman lada perdu pada uji lanjut BNT dengan taraf 5\% disajikan pada Tabel 1. Berdasarkan data rerata diameter batang pada Tabel 1, Perlakuan pemberian konsentrasi giberelin $\left(\mathrm{GA}_{3}\right)$ dan volume semprot pupuk daun tidak menunjukkan adanya pengaruh secara nyata terhadap pertumbuhan diameter batang, Hal ini diduga karena beberapa faktor yang mempengaruhi dari faktor internal maupun faktor eksternal.
Faktor - faktor tersebut seperti daya serap tanaman yang rendah sehingga tidak memberikan pengaruh terhapat pertumbuhan diameter batang tanaman lada perdu. Pengaplikasian perlakuan dilakukan pada daun dan seluruh bagian tanaman namun penyerapan pada batang tanaman tidak maksimal justru dialokasikan untuk perangsangan jumlah cabang pada tanaman lada perdu. Sedangkan faktor eksternal seperti lingkungan, iklim dan cuaca. Faktor lingkungan mempengaruhi keberhasilan pertumbuhan tanaman lada yaitu media perakaran, suhu, kelembaban dan cahaya (Hartman, 1983).

\section{Respons Jumlah Cabang terhadap Pemberian} Konsentrasi Giberelin ( $\left(\mathrm{GA}_{3}\right)$ dan Volume Semprot Pupuk Daun pada Tanaman Lada Perdu

Hasil rata-rata jumlah cabang tanaman lada perdu pada uji lanjut BNT dengan taraf 5\% yang disajikan pada Tabel 2. Berdasarkan Tabel 2, pemberian konsentrasi giberelin $\left(\mathrm{GA}_{3}\right)$ tidak memberikan pengaruh pada jumlah cabang tanaman

Tabel 1. Pengaruh tunggal antara konsentrasi giberelin $\left(\mathrm{GA}_{3}\right)$ dan volume semprot pupuk daun terhadap diameter batang $(\mathrm{mm})$ pada tanaman lada perdu.

\begin{tabular}{lcccc}
\hline \multicolumn{1}{c}{ Perlakuan } & \multicolumn{4}{c}{ Rerata diameter batang (mm) } \\
& 1 BSP & 2 BS P & 3 BSP & 4 BSP \\
\hline Konsentrasi giberelin (GA3) & $0,73 \mathrm{a}$ & $0,73 \mathrm{a}$ & $0,73 \mathrm{a}$ & $0,73 \mathrm{a}$ \\
$\mathrm{G}_{0}=$ kontrol (tan pa giberelin) & $0,86 \mathrm{a}$ & $0,86 \mathrm{a}$ & $0,86 \mathrm{a}$ & $0,86 \mathrm{a}$ \\
$\mathrm{G}_{1}=$ giberelin $50 \mathrm{~mL} \cdot \mathrm{L}^{-1}$ & $0,77 \mathrm{a}$ & $0,77 \mathrm{a}$ & $0,77 \mathrm{a}$ & $0,77 \mathrm{a}$ \\
$\mathrm{G}_{2}=$ giberelin $100 \mathrm{~mL} \cdot \mathrm{L}^{-1}$ & $0,82 \mathrm{a}$ & $0,82 \mathrm{a}$ & $0,82 \mathrm{a}$ & $0,82 \mathrm{a}$ \\
$\mathrm{G}_{3}=$ giberelin $150 \mathrm{~mL} \cdot \mathrm{L}^{-1}$ & $0,76 \mathrm{a}$ & $0,76 \mathrm{a}$ & $0,76 \mathrm{a}$ & $0,76 \mathrm{a}$ \\
$\mathrm{G}_{4}=$ giberelin $200 \mathrm{~mL} \cdot \mathrm{L}^{-1}$ & & & & \\
& & & & \\
$\mathrm{~V}_{\text {olume semprot pupuk daun }}$ & $0,83 \mathrm{a}$ & $0,83 \mathrm{a}$ & $0,83 \mathrm{a}$ & $0,83 \mathrm{a}$ \\
$\mathrm{D}_{0}=$ kontrol (tanpa pupuk daun) & $0,80 \mathrm{a}$ & $0,80 \mathrm{a}$ & $0,80 \mathrm{a}$ & $0,80 \mathrm{a}$ \\
$\mathrm{D}_{1}=$ pupuk daun $100 \mathrm{ml}$ & $0,73 \mathrm{a}$ & $0,73 \mathrm{a}$ & $0,73 \mathrm{a}$ & $0,73 \mathrm{a}$ \\
$\mathrm{D}_{2}=$ pupuk daun $200 \mathrm{ml}$ & &
\end{tabular}

Keterangan: Angka rata-rata yang diikuti oleh huruf yang sama menunjukkan tidak berbeda nyata berdasarkan uji BNT pada $\operatorname{taraf} 5 \%$. 
Tabel 2. Pengaruh mandiri antara konsentrasi giberelin(GA3) dan volume semprot pupuk daun terhadap jumlah cabang (tangkai) pada tanaman lada perdu.

\begin{tabular}{|c|c|c|c|c|}
\hline \multirow{2}{*}{ Perlaku an } & \multicolumn{4}{|c|}{ Rerata jumlah cabang ( tan gkai) } \\
\hline & $1 \mathrm{BSP}$ & 2 B SP & $3 \mathrm{BSP}$ & 4 B SP \\
\hline \multicolumn{5}{|l|}{ K on sentrasi gibere lin (GA 3) } \\
\hline $\mathrm{G}_{0}=\operatorname{kontrol}(\tan p a$ giberelin) & $8,78 \mathrm{a}$ & $14,56 \mathrm{a}$ & $16,94 \mathrm{a}$ & $17,72 \mathrm{a}$ \\
\hline $\mathrm{G}_{1}=$ giberelin $50 \mathrm{~mL} \cdot \mathrm{L}^{-1}$ & $9,22 \mathrm{a}$ & $14,28 \mathrm{a}$ & $18,78 \mathrm{a}$ & $18,00 \mathrm{a}$ \\
\hline $\mathrm{G}_{2}=$ giberelin $100 \mathrm{~mL} \cdot \mathrm{L}^{-1}$ & $13,28 \mathrm{a}$ & 18,78 a & $23,78 \mathrm{a}$ & $19,94 \mathrm{a}$ \\
\hline $\mathrm{G}_{3}=$ giberelin $150 \mathrm{~mL} \cdot \mathrm{L}^{-1}$ & $10,89 \mathrm{a}$ & $18,61 \mathrm{a}$ & $22,44 \mathrm{a}$ & $21,00 \mathrm{a}$ \\
\hline \multirow{2}{*}{$\mathrm{G}_{4}^{5}=$ giber elin $200 \mathrm{~mL} \cdot \mathrm{L}^{-1}$} & $11,83 \mathrm{a}$ & $18,94 \mathrm{a}$ & $22,00 \mathrm{a}$ & $21,17 \mathrm{a}$ \\
\hline & - & - & - & - \\
\hline \multicolumn{5}{|l|}{ Volume semprot pupuk daun } \\
\hline $\mathrm{D}_{0}=$ kontrol (tanpa pupuk daun) & $10,10 \mathrm{a}$ & $15,87 \mathrm{ab}$ & $19,80 \mathrm{a}$ & $18,63 \mathrm{a}$ \\
\hline $\mathrm{D}_{1}=$ pup uk daun $100 \mathrm{ml}$ & $10,80 \mathrm{a}$ & $14,33 \mathrm{a}$ & $21,17 \mathrm{a}$ & $21,47 \mathrm{a}$ \\
\hline $\mathrm{D}_{2}=$ pup uk daun $200 \mathrm{ml}$ & $11,50 \mathrm{a}$ & $20,90 \mathrm{~b}$ & $21,40 \mathrm{a}$ & $18,60 \mathrm{a}$ \\
\hline BNT 5\% & - & 6,41 & - & - \\
\hline
\end{tabular}

Keterangan : Angka rata-rata yang diikuti oleh huruf yang sama menunjukkan tidak berbeda nyata berdasarkan uji BNT pada taraf $5 \%$.

lada perdu, tetapi pada perlakuan volume semprot pupuk daun $200 \mathrm{ml}$ pengamatan (2 BSP) menunjukkan adanya pengaruh yang meningkatkan jumlah cabang pada tanaman lada perdu, dengan nilai yang lebih tinggi dibandingkan dengan kontrol (tanpa pupuk daun) dan volume semprot pupuk daun $100 \mathrm{ml}$. Perlakuan volume semprot pupuk daun $200 \mathrm{ml}$ diduga mampu meningkatkan jumlah cabang pada tanaman lada perdu dengan penyerapan unsur hara yang cenderung lebih tinggi terdapat pada pupuk daun.

Hasil penelitian Satriyo dan Nurul (2018) pada tanaman terong menggunakan pupuk daun Growmore peningkatan terjadi pada tingkat konsentrasi 3 g.L-1 yang menunjukkan bahwa terjadi interaksi antara jenis pupuk daun dengan tingkat konsentrasi pupuk daun pada tinggii tanaman, jumlah daun, jumlah cabang, luas daun, bobot buah per tanaman, bobot buah per buah, tetapi tidak terjadi interaksi pada jumlah buah dan berat kering total tanaman. Pada pertumbuhan vegetatif, tanaman lebih banyak membutuhkan pupuk dengan kandungan unsur nitrogen $(\mathrm{N})$ yang tinggi, sedangkan saat masuk ke fase generatif tanaman lebih banyak membutuhkan pupuk dengan kandungan unsur fosfor (P) dan kalium (K) yang tinggi (Hendaryono, 1998).

\section{Respons Jumlah Ruas terhadap Pemberian} Konsentrasi Giberelin $\left(\mathrm{GA}_{3}\right)$ dan Volume Semprot Pupuk Daun pada Tanaman Lada Perdu.

Hasil rata-rata jumlah ruas tanaman lada perdu pada uji lanjut BNT dengan taraf 5\% disajikan pada Tabel 3. Tabel 3 menunjukkan bahwa pemberian perlakuan volume semprot pupuk daun tidak memberikan pengaruh pada jumlah ruas tanaman lada perdu namun pada pemberian perlakuan konsentrasi giberelin $\left(\mathrm{GA}_{3}\right) \quad 150 \mathrm{~mL} \mathrm{~L}^{-1}$ pengamatan $4 \mathrm{BSP}$ menunjukkan nilai yang tertinggi. Dibandingkan dengan kontrol (tanpa giberelin), konsentrasi giberelin $\left(\mathrm{GA}_{3}\right)$ $50 \mathrm{~mL} \mathrm{~L}^{-1}$, konsentrasi giberelin $\left(\mathrm{GA}_{3}\right) 100 \mathrm{~mL} \mathrm{~L}^{-1}$ dan konsentrasi giberelin $\left(\mathrm{GA}_{3}\right) 200 \mathrm{~mL} \mathrm{~L}^{-1}$. Dengan hasil tersebut maka perlakuan konsentrasi giberelin $\left(\mathrm{GA}_{3}\right) 150 \mathrm{~mL} \mathrm{~L}^{-1}$ memberikan pengaruh yang 
Tabel 3. Pengaruh mandiri antara konsentrasi giberelin(GA3) dan volume semprot pupuk daun terhadap jumlah ruas (buah) pada tanaman lada perdu.

\begin{tabular}{|c|c|c|c|c|}
\hline \multirow{2}{*}{ Perlakuan } & \multicolumn{4}{|c|}{ Rerata jumlah ruas (buah) } \\
\hline & $1 \mathrm{BSP}$ & 2 BSP & $3 \mathrm{BSP}$ & $4 \mathrm{BSP}$ \\
\hline \multicolumn{5}{|l|}{ Konsentrasi giberelin (GA3) } \\
\hline $\mathrm{G}_{0}=$ kontrol (tanpa giberelin) & $29,00 \mathrm{a}$ & 46,33 a & $51,78 \mathrm{a}$ & $49,56 \mathrm{a}$ \\
\hline $\mathrm{G}_{1}=$ giberelin $50 \mathrm{~mL} \cdot \mathrm{L}^{-1}$ & $33,56 \mathrm{a}$ & $52,83 \mathrm{a}$ & $66,44 \mathrm{a}$ & $63,28 \mathrm{a}$ \\
\hline $\mathrm{G}_{2}=$ giberelin $100 \mathrm{~mL} \cdot \mathrm{L}^{-1}$ & $42,11 \mathrm{a}$ & 63,89 a & $76.28 \mathrm{a}$ & $66,17 \mathrm{a}$ \\
\hline $\mathrm{G}_{3}=$ giberelin $150 \mathrm{~mL} \cdot \mathrm{L}^{-1}$ & $41,00 \mathrm{a}$ & $64,50 \mathrm{a}$ & $75,28 \mathrm{a}$ & $81,67 \mathrm{~b}$ \\
\hline $\mathrm{G}_{4}=$ giberelin $200 \mathrm{~mL} \cdot \mathrm{L}^{-1}$ & $38,50 \mathrm{a}$ & $59,56 \mathrm{a}$ & $68,78 \mathrm{a}$ & $67,17 \mathrm{a}$ \\
\hline BNT $5 \%$ & - & - & - & 14,3 \\
\hline \multicolumn{5}{|l|}{ Volume semprot pupuk daun } \\
\hline $\mathrm{D}_{0}=$ kontrol (tanpa pupuk daun) & $34,23 \mathrm{a}$ & $53,20 \mathrm{a}$ & $62,30 \mathrm{a}$ & $61,93 \mathrm{a}$ \\
\hline $\mathrm{D}_{1}=$ pupuk daun $100 \mathrm{ml}$ & $37,73 \mathrm{a}$ & $55,60 \mathrm{a}$ & $70,70 \mathrm{a}$ & $67,83 \mathrm{a}$ \\
\hline $\mathrm{D}_{2}=$ pupuk daun $200 \mathrm{ml}$ & $38,53 \mathrm{a}$ & 63,47 a & 69,83 a & $66,93 \mathrm{a}$ \\
\hline
\end{tabular}

Keterangan : Angka rata-rata yang diikuti oleh huruf yang sama menunjukkan tidak berbeda nyata berdasarkan uji BNT pada taraf $5 \%$.

meningkatkan jumlah ruas tanaman lada perdu dan diduga bahwa perlakuan konsentrasi giberelin $\left(\mathrm{GA}_{3}\right)$ $150 \mathrm{~mL} \mathrm{~L}^{-1}$ mampu merangsang pertumbuhan jumlah ruas pada tanaman lada dengan penyerapan yang lebih tinggi.

Annisa (2009) menyatakan bahwasalah satu zat kimia yang diperlukan tanaman adalah giberelin. Giberelin terdapat dalam berbagai organ: akar, batang, tunas, daun, tunas-tunas bunga, bintil akar, buah, dan jaringan kalus.Giberelin dapat merangsang proses perkecambahan biji, giberelin juga akan merangsang pemanjangan batang dengan merangsang pembelahan sel sehingga sel akan memanjang, selain itu giberelin akan merangsang dan mempertinggi prosentase timbulnya bunga dan buah karena giberelin dapat merangsang pembungaan serta dapat mengurangi gugurnya bunga dan buah sebelum waktunya. Hormon berkerja untuk menginduksi pertumbuhan dalam konsentrasi yang tepat, namun apabila konsentrasi berlebih atau kurang maka hormon akan menghambat pertumbuhan (Latunra, 2012).

\section{Respons Waktu Berbunga terhadap Pemberian} Konsentrasi Giberelin $\left(\mathrm{GA}_{3}\right)$ dan Volume Semprot Pupuk Daun pada Tanaman Lada Perdu.

Hasil rerata waktu berbunga tanaman lada perdu pada uji lanjut BNT dengan taraf 5\% disajikan pada Tabel 4. Berdasarkan Tabel 4, perlakuan pemberian konsentrasi giberelin $\left(\mathrm{GA}_{3}\right)$ dan volume semprot pupuk daun tidak menunjukkan adanya pengaruh secara nyata terhadap waktu berbunga tanaman lada perdu. Hal ini diduga karna beberapa faktor yang mempengaruhi seperti faktor iklim yang ekstrim. Prioritas penyemprotan saat aplikasi yaitu pada bagian bawah daun karena paling banyak terdapat stomata. Cuaca yang panas dan curah hujan yang tidak menentu diduga menjadi salah satu faktor waktu 
Tabel 4. Pengaruh mandiri antara konsentrasi giberelin $\left(\mathrm{GA}_{3}\right)$ dan volume semprot pupuk daun terhadap waktu berbunga (hari setelah perlakuan) pada tanaman lada perdu.

\begin{tabular}{|c|c|}
\hline Perlakuan & $1 \mathrm{BSP}$ \\
\hline 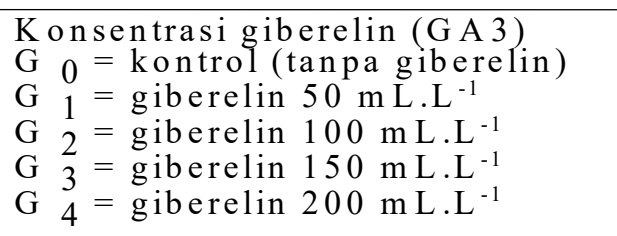 & $\begin{array}{l}24,78 \mathrm{a} \\
25,78 \mathrm{a} \\
24,78 \mathrm{a} \\
24,44 \mathrm{a} \\
22,56 \mathrm{a}\end{array}$ \\
\hline $\begin{array}{l}\text { Volume semprot pupuk daun } \\
\mathrm{D} 0^{=} \text {kontrol (tanpa pupuk daun) } \\
\mathrm{D} 1 \text { = pupuk daun } 100 \mathrm{~m} 1 \\
\mathrm{D}_{2}=\text { pupukdaun } 200 \mathrm{~m} 1\end{array}$ & $\begin{array}{l}23,47 \mathrm{a} \\
24,73 \mathrm{a} \\
25,20 \mathrm{a}\end{array}$ \\
\hline
\end{tabular}

Keterangan : Angka rata-rata yang diikuti oleh huruf yang sama menunjukkan tidak berbeda nyata berdasarkan uji BNT pada taraf $5 \%$.

Tabel 5. Interaksi konsentrasi giberelin $\left(\mathrm{GA}_{3}\right)$ dan volume semprot pupuk daun terhadap jumlah bunga (tangkai) pada tanaman lada perdu.

\begin{tabular}{lcccccc}
\hline \multirow{2}{*}{$\begin{array}{l}\text { Volume semprot } \\
\text { pupuk daun (D) }\end{array}$} & $\mathrm{G}\left(0 \mathrm{~mL} \cdot \mathrm{L}^{-1}\right)$ & $\mathrm{G} 1\left(50 \mathrm{~mL} \cdot \mathrm{L}^{-1}\right) \mathrm{G} 2\left(100 \mathrm{~mL} \cdot \mathrm{L}^{-1}\right) \mathrm{G} 3\left(150 \mathrm{~mL} \cdot \mathrm{L}^{-1}\right)$ & $\mathrm{G} 4\left(200 \mathrm{~mL} \cdot \mathrm{L}^{-1}\right)$ & Rerata (D) \\
\cline { 2 - 7 } $\mathrm{D} 0(0 \mathrm{ml})$ & $4,00 \mathrm{a}$ & $4,20 \mathrm{a}$ & $14,00 \mathrm{~b}$ & $10,30 \mathrm{a}$ & $9,20 \mathrm{a}$ & 8,34 \\
$\mathrm{D} 1(100 \mathrm{ml})$ & $8,80 \mathrm{a}$ & $11,30 \mathrm{~b}$ & $15,80 \mathrm{~b}$ & $5,50 \mathrm{a}$ & $13,50 \mathrm{~b}$ & 10,98 \\
$\mathrm{D} 2(200 \mathrm{ml})$ & $14,70 \mathrm{~b}$ & $11,70 \mathrm{~b}$ & $4,80 \mathrm{a}$ & $8,70 \mathrm{a}$ & $13,70 \mathrm{~b}$ & 10,72 \\
Rerata $(\mathrm{G})$ & 9,16 & 9,06 & 11,53 & 8,16 & 12,13 & \\
\hline
\end{tabular}

BNT $5 \%$ 6,79

Keterangan : Angka rata-rata yang diikuti oleh huruf yang sama menunjukkan tidak berbeda nyata berdasarkan uji BNT pada taraf $5 \%$.

berbunga tanaman lada perdu tidak berbeda secara signifikan. Apabila terjadi hujan maka akan mengurangi efektivitas penyerapan pupuk daun growmore dan hormon giberelin $\left(\mathrm{GA}_{3}\right)$.

Penyemprotan perlakuan saat suhu udara panas menyebabkan konsentrasi larutan giberelin $\left(\mathrm{GA}_{3}\right)$ dan pupuk daun growmore yang sampai ke daun cepat meningkat sehingga daun dapat terbakar (Prasetya, 2011). Hal tersebut terjadi bila didukung dengan iklim dan cuaca yang baik bagi pertumbuhan waktu berbunga pada tanaman.Dengan dipengaruhi oleh berbagai faktor seperti faktor lingkungan, iklim, suhu, sinar cahaya matahari, faktor eksternal lainnya maka waktu berbunga pada tanaman lada perdu cenderung lebih seragam tidak terlihat signifikan. Penelitian Arifin dkk., (2014) pada cabai merah keriting dengan pemberian GA3 dengan konsentrasi 0, 20, 40 dan $60 \mathrm{~mL} \mathrm{~L}^{-1}$ menunjukkan bahwa Konsentrasi sebesar $56 \mathrm{~mL} \mathrm{~L}^{-1}$ optimal pada variabel umur berbunga.

Respons Jumlah Bunga terhadap Pemberian Konsentrasi Giberelin $\left(\mathrm{GA}_{3}\right)$ dan Volume Semprot Pupuk Daun pada Tanaman Lada Perdu.

Perlakuan konsentrasi giberelin $\left(\mathrm{GA}_{3}\right)$ dan volume semprot pupuk daun pada variabel jumlah bunga menunjukan adanya interaksi antar kedua 
perlakuan tersebut pada pengamatan (1 BSP) pada uji lanjut BNT dengan taraf 5\% disajikan pada Tabel 5. Berdasarkan Tabel 5. menunjukan bahwa adanya interaksi antara perlakuan konsentrasi giberelin $\left(\mathrm{GA}_{3}\right)$ $100 \mathrm{~mL} \mathrm{~L}^{-1}$ dan volume semprot pupuk daun $100 \mathrm{ml}$ dengan nilai tertinggiyaitu 15,80 . Hal ini diduga pemberian konsentrasi giberelin $\left(\mathrm{GA}_{3}\right) 100 \mathrm{~mL} \mathrm{~L}^{-1}$ bila dikombinasikan dengan pemberian volume semprot pupuk daun $100 \mathrm{ml}$ mampu dalam hal meningkatkan jumlah bunga pada tanaman lada perdu. Interaksi juga terjadi pada perlakuan konsentarsi giberelin $\left(\mathrm{GA}_{3}\right) 0$ $\mathrm{mLL}^{-1}$ dan volume semprot $200 \mathrm{ml}$ untuk meningkatkan jumlah bunga tanaman lada perdu yang lebih ekonomis karena harga giberelin $\left(\mathrm{GA}_{3}\right)$ cenderung mahal sehingga pada interaksi tersebut lebih direkomendasikan. Giberelin akan mampu mempertinggi prosentase timbulnya bunga dan buah karena giberelin dapat merangsang pembungaan serta dapat mengurangi gugurnya bunga dan buah. Terdapat pula beberapa penelitian yang menunjukkan bahwa penggunaan pupuk daun dapat meningkatkan pertumbuhan tanaman dan serapan hara pada tanaman lada perdu (Rahmayani, 2006).

Pemupukan lewat daun diharapkan dapat meningkatkan efektivitas hara tanaman mengingat pemupukan melalui tanah yang kurang menguntungkan bagi tanaman karena akan sering mengalami pencucian, sehingga timbul alasan untuk melakukan pemupukan melalui daun. Daun memiliki mulutyang dikenal dengan nama stomata. Sebagian besar stomata terletak di bagian bawah daun. Fungsi stomata untuk mengatur penguapan air dari tanaman sehingga air dari akar dapat sampai ke daun. Saat suhu udara meningkat, stomata akan menutup sehingga tanaman tidak akan mengalami kekeringan. Sebaliknya, jika udara tidak terlalu panas, stomata akan membuka sehingga air yang ada di permukaan daun dapat masuk dalam jaringan daun. Dengan sendirinya unsur hara yang disemprotkan ke permukaan daun juga masuk ke dalam jaringan daun (Prasetya, 2011).

Tabel 6. Pengaruh mandiri antara konsentrasi giberelin $\left(\mathrm{GA}_{3}\right)$ dan volumesemprot pupuk daun terhadap jumlah buah (tangkai) pada tanaman lada perdu.

\begin{tabular}{|c|c|c|}
\hline \multirow{2}{*}{ Perlakuan } & \multicolumn{2}{|c|}{ Rerata jumlah buah (tangkai) } \\
\hline & $3 \mathrm{BSP}$ & $4 \mathrm{BSP}$ \\
\hline Konsentrasi giberelin (GA3) & & \\
\hline $\mathrm{G}_{0}=$ kontrol (tanpa giberelin) & $3,61 \mathrm{a}$ & $3,83 \mathrm{a}$ \\
\hline $\mathrm{G}_{1}=$ giberelin $50 \mathrm{~mL} \cdot \mathrm{L}^{-1}$ & $4,00 \mathrm{a}$ & $6,00 \mathrm{a}$ \\
\hline $\mathrm{G}_{2}^{1}=$ giberelin $100 \mathrm{~mL} \cdot \mathrm{L}^{-1}$ & $8,00 \mathrm{~b}$ & $8,00 \mathrm{ab}$ \\
\hline $\mathrm{G}_{3}=$ giberelin $150 \mathrm{~mL} \cdot \mathrm{L}^{-1}$ & $7,83 \mathrm{~b}$ & $7,56 \mathrm{ab}$ \\
\hline $\mathrm{G}_{4}=$ giberelin $200 \mathrm{~mL} \cdot \mathrm{L}^{-1}$ & $8,72 \mathrm{~b}$ & $8,89 \mathrm{~b}$ \\
\hline BNT 5\% & 3,02 & 2,28 \\
\hline Volume semprot pupuk daun & & \\
\hline $\mathrm{D}_{0}=$ kontrol (tanpa pupuk daun) & $5,70 \mathrm{a}$ & $5,13 \mathrm{a}$ \\
\hline $\mathrm{D}_{1}=$ pupuk daun $100 \mathrm{ml}$ & $6,97 \mathrm{a}$ & $7,17 \mathrm{a}$ \\
\hline $\mathrm{D}_{2}=$ pupuk daun $200 \mathrm{ml}$ & $6,63 \mathrm{a}$ & $8,27 \mathrm{a}$ \\
\hline BNT 5\% & 3,9 & 3,34 \\
\hline
\end{tabular}

Keterangan : Angka rata-rata yang diikuti oleh huruf yang sama menunjukkan tidak berbeda nyata berdasarkan uji BNT pada taraf $5 \%$. 
Respons Jumlah Buah terhadap Pemberian Konsentrasi Giberelin (GA) dan Volume Semprot

\section{Pupuk Daun pada Tanaman Lada Perdu.}

Hasil rata-rata jumlah buah tanaman lada perdu pada uji lanjut BNT dengan taraf $5 \%$ disajikan pada Tabel 6. Berdasarkan Tabel 6, pemberian perlakuan volume semprot pupuk daun tidak memberikan pengaruh pada jumlah ruas tanaman lada perdu, tetapi pada pemberian perlakuan konsentrasi giberelin $\left(\mathrm{GA}_{3}\right)$ $200 \mathrm{~mL} \mathrm{~L}^{-1}$ pada setiap pengamatan menunjukkan nilai yang lebih tinggi yaitu 8,89 . Dibandingkan dengan kontrol (tanpa giberelin), konsentrasi giberelin $\left(\mathrm{GA}_{3}\right)$ $50 \mathrm{~mL} \mathrm{~L}^{-1}$, konsentrasi giberelin $\left(\mathrm{GA}_{3}\right) 100 \mathrm{~mL} \mathrm{~L}^{-1}$ dan konsentrasi giberelin $\left(\mathrm{GA}_{3}\right) 150 \mathrm{~mL} \mathrm{~L}^{-1}$. Dengan hasil tersebut maka perlakuan konsentrasi giberelin $\left(\mathrm{GA}_{3}\right)$ $200 \mathrm{~mL} \mathrm{~L}^{-1}$ memberikan pengaruh secara nyata pada jumlah buah tanaman lada perdu dan diduga bahwa perlakuan konsentrasi giberelin $\left(\mathrm{GA}_{3}\right) 200 \mathrm{~mL} \mathrm{~L}^{-1}$ mampu merangsang pertumbuhan jumlah buah pada tanaman lada dengan penyerapan yang lebih tinggi.
Giberelin $\left(\mathrm{GA}_{3}\right)$ yang memiliki banyak peran dalam mempengaruhi berbagai proses fisiologi tanaman (Maharani dkk., 2018). Pada pengamatan variabel jumlah bunga menunjukan bunga yang lebat namun pada tidak selaras dengan jumlah buah, hal ini diduga bahwa adanya faktor eksternal seperti angin kencang, curah hujan yang tinggi dan lainnya sehingga menyebabkan bunga gugur sebelum berubah menjadi buah. Bunga yang gugur berjatuhan di sekitar pot dan tak hanya bunga yang gugur tetapi ada tangkai buah juga yang gugur dikarenakan angin kencang dan cuaca buruk pada sekitar daerah penelitian.

\section{Respons Bobot Buah terhadap Pemberian} Konsentrasi Giberelin $\left(\mathrm{GA}_{3}\right)$ dan Volume Semprot Pupuk Daun pada Tanaman Lada Perdu.

Hasil rata-rata bobot buah tanaman lada perdu pada uji lanjut BNT dengan taraf 5\% disajikan pada Tabel 7. Tabel 7 menunjukkan bahwa pemberian perlakuan volume semprot pupuk daun tidak memberikan pengaruh pada bobot buah tanaman lada

Tabel 7. Pengaruh mandiri antara konsentrasi giberelin $\left(\mathrm{GA}_{3}\right)$ dan volume semprot pupuk daun terhadap bobot buah (gram) pada tanaman lada perdu.

\begin{tabular}{|c|c|}
\hline Perlakuan & $\begin{array}{l}\text { Rerata bobot buah (gram) } \\
4 \text { BSP }\end{array}$ \\
\hline Konsentrasi giberelin (GA3) & \\
\hline $\mathrm{G}_{0}=$ kontrol (tanpa giber elin) & $3,73 \mathrm{a}$ \\
\hline $\mathrm{G}_{1}=$ giberelin $50 \mathrm{~mL} \cdot \mathrm{L}^{-1}$ & $4,70 \mathrm{a}$ \\
\hline $\mathrm{G}_{2}=$ giberelin $100 \mathrm{~mL} \cdot \mathrm{L}^{-1}$ & $8,54 \mathrm{ab}$ \\
\hline $\mathrm{G}_{3}=$ giberelin $150 \mathrm{~mL} \cdot \mathrm{L}^{-1}$ & $6,38 \mathrm{a}$ \\
\hline $\mathrm{G}_{4}^{\mathrm{J}}=$ giberelin $200 \mathrm{~mL} \cdot \mathrm{L}^{-1}$ & $9,66 \mathrm{~b}$ \\
\hline BNT 5\% & 2,85 \\
\hline Volume semprot pupuk daun & \\
\hline $\mathrm{D}_{0}=$ kontrol (tanpa pupuk daun) & $5,39 \mathrm{a}$ \\
\hline $\mathrm{D}_{1}=$ pupuk daun $100 \mathrm{ml}$ & $6,55 \mathrm{a}$ \\
\hline $\mathrm{D}_{2}=$ pupuk daun $200 \mathrm{ml}$ & $7,86 \mathrm{a}$ \\
\hline
\end{tabular}

$\frac{3,68}{\text { BNT 5\% }}$ taraf $5 \%$. 
perdu, tetapi pada pemberian perlakuan konsentrasi giberelin (GA G $_{3} 200 \mathrm{~mL} \mathrm{~L}^{-1}$ menunjukkan nilai yang lebih tinggi yaitu 9,66 dibandingkan dengan kontrol (tanpa giberelin), konsentrasi giberelin $\left(\mathrm{GA}_{3}\right) 50 \mathrm{~mL}$ $\mathrm{L}^{-1}$, konsentrasi giberelin $\left(\mathrm{GA}_{3}\right) 100 \mathrm{~mL} \mathrm{~L}^{-1}$ dan konsentrasi giberelin $\left(\mathrm{GA}_{3}\right) 150 \mathrm{mLL}^{-1}$. Dengan hasil tersebut maka perlakuan konsentrasi giberelin $\left(\mathrm{GA}_{3}\right)$ $200 \mathrm{~mL} \mathrm{~L}^{-1}$ memberikan pengaruh secara nyata pada bobot buah tanaman lada perdu dan diduga bahwa perlakuan konsentrasi giberelin $\left(\mathrm{GA}_{3}\right) 200 \mathrm{~mL} \mathrm{~L}^{-1}$ mampu merangsang pertumbuhan bobot buah pada tanaman lada dengan penyerapan yang lebih tinggi. Penelitian lainnya jugamenunjukkan pemberian giberalin memiliki pengaruh yang signifikan pada pertumbuhan, kualitas dan hasil tomat pada konsentrasi $50 \mathrm{~mL} \mathrm{~L}^{-1}$ (Akash dkk., 2014).

\section{KESIMPULAN}

Kesimpulan yang dapat diambil adalah pemberian giberelin $\left(\mathrm{GA}_{3}\right)$ dengan konsentrasi $150 \mathrm{~mL}$ $\mathrm{L}^{-1}$ dapat meningkatkan jumlah ruas, sedangkan pemberian giberelin $\left(\mathrm{GA}_{3}\right)$ dengan konsentrasi $200 \mathrm{~mL}$ $\mathrm{L}^{-1}$-dapat meningkatkan jumlah buah dan bobot buah pada tanaman lada perdu, pemberian volume semprot pupuk daun $200 \mathrm{ml}$ dapat meningkatkan jumlah cabang pada tanaman lada perdu dan pemberian konsentrasi giberelin $\left(\mathrm{GA}_{3}\right) 100 \mathrm{~mL} \mathrm{~L}^{-1}$ yang dikombinasikan dengan volume semprot pupuk daun $100 \mathrm{ml}$ dapat meningkatkan jumlah bunga pada tanaman lada perdu.

\section{UCAPAN TERIMA KASIH}

Ucapan terima kasih kami sampaikan kepada Direktur Politeknik Negeri Lampung yang telah memberikan Dana DIPA Politeknik Sehingga terlaksananya penelitian ini dan Ketua Jurusan Budidaya Tanaman Perkebunan yang mensuport penelitian hingga akhir.

\section{DAFTAR PUSTAKA}

Akash K., Tarun K. Biswas, and Neha. 2014.Effect of Gibberellic Acid on Growth, Quality and Yield of Tomato(Lycopersicon esculentum Mill.). Uttar Pradesh. Journal of Agriculture and Veterinary Science (IOSR-JAVS) Volume 7, Issue 7 Ver. IV.

Annisa. 2009. Pengaruh Induksi Giberelin terhadap Pemebentukan Buah Partenokarpi Pada Beberapa Varietas Tanaman Semangka (Citrulus vulgaris Schard). Skripsi Fakultas Pertgantianian Universitas Sumatra Utara, Medan.

Arifin,Z., Yudono, P., danToekidjo.2014. Pengaruh Konsentrasi GA3 terhadap Pembungaan dan Kualitas Benih Cabai Merah Keriting (Capsicum annuum L.) Vegetalika. 1 (4) :128-140.

Direktorat Jenderal Perkebunan. 2017. Statistika Perkebunan Indonesia. Jakarta.

Hartman, H. E. dan Kester, D.E. 1983. Plant Propagation Principle and Practise. Buku. Engelwoods Clifs. New Jersy. 912 p.

Hendaryono, D.P.S. 1998. Budidaya Anggrek Dengan Bibit dalam Botol. Kanisius. Yogyakarta.

Kementerian Pertanian. 2013. Mengenal jenis jenis varietas lada. http://ditjenbun.pertanian.go.id/ tanregar/berita-230-mengenal-jenisjenis varietas-lada.html. Jakarta. 
Latunra, A. I., 2012. Penuntun Praktikum Fisiologi Tumbuhan II. Universitas Hasanuddin. Makasar.

Maharani, A., Suwirmen., Noli. Z.A. 2018. Pengaruh Konsentrasi Giberelin (GA3) terhadap Pertumbuhan Kailan (Brassica oleracea L. Var alboglabra) pada Berbagai Media Tanam dengan Hidroponik Wick System. Jurnal Biologi

Prasetya. 2011. Mekanisme dan Efektivitas Penyerapan pupuk Melalui daun.

Rahmayani. 2006. Efektifitas Pupuk Pelengkap Cair Dharmavit Terhadap Pertumbuhan, Produksi, Serta Serapan Hara N, P, K Tanaman Padi Sawah (Oryza sativa l.) Varietas IR 64 Pada Latosol Darmaga. Skripsi S1 Departemen Ilmu Tanah dan Sumberdaya Lahan, Fakultas Pertanian, Institut Pertanian Bogor.

Satriyo, M. A. dan Nurul, A. 2018. Pengaruh Jenis Dan Tingkat Konsentrasi Pupuk Daun Terhadap Pertumbuhan Dan Hasil Tanaman
Terong (Solanum melongena L.). jurnal produksi tanaman Vol. 6 No. 7, Juli 2018: 1473 - 1480. Department of Agronomy. Faculty of Agriculture. Brawijaya University. Jawa Timur.

Srinivasan. K. 2007.Black pepper and its pungent principle-piperine: A reviewof diverse physiological effects. Critical Rev. Food Nut. 47:735-748.

Sunardi, Ardimihardja dan Mulyaningsih. 2013. Pengaruh Tingkat Pemberian ZPT Giberelin $\left(\mathrm{GA}_{3}\right)$ Terhadap Pertumbuhan Vegetatif Tanaman Kangkung Air (Ipomea aquatica Forsk L.) Pada Sistem Hidroponik Floating Raft Technique (FRT). Jurnal Pertanian Issn 2087-4936 Volume 4 Nomor 1, April 2013. Universitas Djuanda Bogor.

Yasmin S., Wardiyati, T. dan Koesrihati. 2014. Pengaruh Perbedaan Waktu Aplikasi dan Konsentrasi $\left(\mathrm{GA}_{3}\right)$ Terhadap Pertumbuhan Dan Hasil Tanaman Cabai Besar (Capsicumannum L.). 